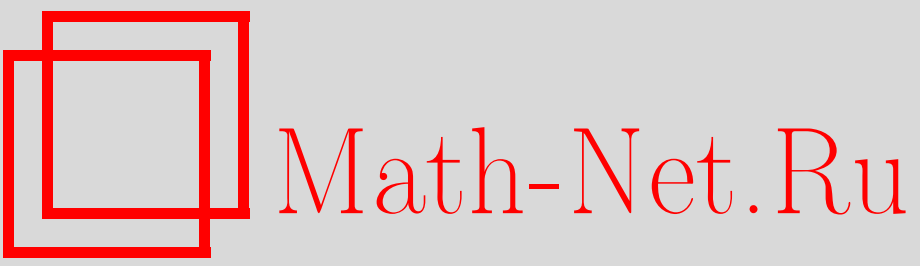

В. В. Гусев, Ю. В. Покорный, П. Л. Ульянов, Школа “Современные методы теории функций и смежные проблемы", УМН, 1997, том 52, выпуск 4, 251-252

DOI: https://doi.org/10.4213/rm1598

Использование Общероссийского математического портала Math-Net.Ru подразумевает, что вы прочитали и согласны с пользовательским соглашением

http://www.mathnet.ru/rus/agreement

Параметры загрузки:

IP: 35.173 .137 .237

26 апреля 2023 г., 13:00:28 


\title{
ШКОЛА “СОВРЕМЕННЫЕ МЕТОДЫ ТЕОРИИ ФУНКЦИЙ И СМЕЖНЫЕ ПРОБЛЕМЫ"
}

\begin{abstract}
Школа была организована НИИ математики Воронежского государственного университета (НИИМ ВГУ) совместно с Московским университетом и МИРАН им. В. А. Стеклова и проведена с 28 января по 4 февраля 1997 г. в курортной зоне г. Воронежа.

Основные научные направления программы школы: ортогональные полиномы и ряды, приближения функций многих переменных, аппроксимация функций полиномами действительного и комплексного переменного, граничные свойства аналитических функций, приближение в функциональных пространствах, а также оптималшное управление, спектральная теория дифференциальных операторов, современные разделы качественной теории краевых задач.

В работе школы приняло участие более 100 человек из 26 городов, 28 представителей из Москвы, 37 из Воронежа, по 5 представителей из Саратова и Ростова-на-Дону, 3 из Самары, по 2 представителя прислали Екатеринбург, Казань, Владимир. В конференции были представлены математики России, Украины, Белоруссии, Казахстана, Азербайджана. В числе участников школы 28 аспирантов и студентов, 40 кандидатов и 28 докторов наук, академик Высшей школы, два член-корреспондента и академик РАН.
\end{abstract}

В состав оргкомитета вошли:

П. Л. Ульянов (Москва) - председатель, В. В. Гусев (Воронеж) - зам. председателя, Ю. В. Покорньй (Воронеж) - зам. председателя, Э.К. Алгазинов (Воронеж), Б. И. Голубов (Долгопрудньй), Б. С. Кашин (Москва), Ю. Ф. Коробейник (Ростов-на-Дону), В. З. Мешков (Воронеж), В. В. Михальский (Воронеж), М. С. Никольский (Москва), А. И. Перов (Воронеж), В. В. Провоторов (Воронеж) - уч. секретарь, Е. М. Семенов (Воронеж), Ю. Н. Субботин (Екатеринбург), В.П. Трофимов (Воронеж), А. П. Хромов (Саратов).

Были прочитаны лекции:

Седлецкий А. М. (Москва) Аппроксимация посредством экспонент на всей прямой.

Субботин Ю.Н. (Екатеринбург) Базисы всплесков в пространстве аналитических в круге функций.

Ульянов П. Л. (Москва) О множителях Вейля.

Ильин В. А. (Москва) Многомерный оператор Шрёдингера с сингулярным потенциалом.

Абанин А. В. (Ростов-на-Дону) Пространства ульрадифференцируемых функций.

Кашин Б. С. (Москва) $n$-членные приближения.

Хромов А. П. (Саратов) Спектральный анализ интегральных операторов с ядрами с особенностями на диагоналях.

Насыров С. Р. (Казань) Задача Левнера-Хопфа и ее приложения в теории функций и механике. Бахтин И.А. (Воронеж) Существование положительных собственных векторов положительных монотонных однородных операторов.

Сапронов Ю. И., Даринский Б. М. (Воронеж) Фазовые переходы в кристаллах.

Долженко Е.П. (Москва) Новые резултаты в теории полианалитических функций.

Покорньй Ю. В. (Воронеж) Первообразные по Стилтьесу в дифференциальных уравнениях.

Голубов Б. И. (Москва) Операторы Харди и Харди-Литтлвуда в пространствах $H^{1}$ и ВМО.

Кожанов А.И. (Новосибирск) Вырождающиеся уравнения соболевского типа.

Семенов Е.М. (Воронеж) Константа Юнга. 
Осколков В.А. (Москва) Рост цельх функций.

Дубинин В.Н. (Владивосток) Изопериметрические неравенства для емкостей множеств и конденсаторов.

В секциях были представлены выступления двух типов: получасовые доклады и 15-20 минутные сообщения:

секция "Теория приближений” - 7 докладов, 14 сообщений;

секция "Функциональньй анализ" - 4 доклада, 6 сообщений;

секция "Ортогональные полиномы и ряды" - 2 доклада, 3 сообщения;

секция "Комплексньй анализ" - 2 доклада, 3 сообщения;

секция "Обыкновенные дифференциальные уравнения" - 2 доклада, 13 сообщений;

секция "Уравнения в частных производных" - 1 доклад, 9 сообщений;

секция "Механика, моделирование, управление" - 1 доклад, 14 сообщений.

Во время работы школы проводились экскурсии по г. Воронежу (осмотр церквей, женского монастыря, мест, связанных со строительством русского флота), посещение музея изобразительных искусств, театра. Участники имели возможность насладиться пешими и лыжными прогулками по зимнему лесу.

Тезисы опубликованы к началу работы школы.

По мнению всех участников школы, она оказалась интересной и полезной и для провинциальных, и для столичных математиков и прошла успешно, несмотря на значительные финансовые трудности, испытьваемые сейчас наукой и высшей школой.

В.В. Гусев, Ю.В. Покорный, П. Л. Ульянов 